FACTA UNIVERSITATIS

Series: Physical Education and Sport, Vol. 16, No 3, 2018, pp. 687 - 696

https://doi.org/10.22190/FUPES171010061S

Research article

\title{
ASSESSMENT OF BALANCE IN YOUNGER SCHOOL AGE CHILDREN WITH INTELLECTUAL DISABILITY
}

\author{
UDC 796.012.1 \\ 376.4:-053.2
}

\author{
Ivana Sretenović ${ }^{1}$, Goran Nedović ${ }^{1}$, Srboljub Đorđevic ${ }^{2}$ \\ ${ }^{1}$ Faculty for Special Education and Rehabilitation, University of Belgrade, Belgrade, Serbia \\ ${ }^{2}$ Teacher-Training Faculty in Vranje, University of Niš, Vranje
}

\begin{abstract}
In children, balance develops in everyday activities through play and exercise. It is essential for learning, and participation in educational work and physical activities. The aim of this study was to evaluate the balance abilities of younger children with typical development and children with moderate intellectual disability. The survey was conducted on a sample of 38 male children (23 with typical development and 15 with moderate intellectual disability). To assess the balance we used Bruininks - Oseretsky Test of Motor Proficiency, 2nd edition - BOT 2 (Bruininks \& Bruininks, 2005), subtest 5. The results show that the total average achievement of children with typical development for all the tasks was 31.07, and 11.34 for children with intellectual disability. A statistically significant difference was achieved on 6 of the 9 tasks ( $p<0.05$ ). Compared to the norms, children with typical development are within the average range, while participants with moderate intellectual disabilities are below average on a balance test. The obtained results of this study can be used as a basis for further research in the field of (special) education and rehabilitation. They can be used to create programs of preventive and corrective work in order to support and assist students in school activities as well.
\end{abstract}

Key words: BOT-2, children with intellectual disabilities, children with typical development, motor abilities

Received October 10, 2017 / Accepted December 13, 2018

Corresponding author: Ivana Sretenović

University of Belgrade, Faculty for Special Education and Rehabilitation, Visokog Stevana 2, 11000 Belgrade, Serbia Phone: +381 $112183036 •$ E-mail: ivana.sretenovic011@ gmail.com 


\section{INTRODUCTION}

Motor abilities are one of the fundamental existential traits of human personality. Zatsiorsky (1975) considers motor abilities those aspects of motor activity that occur in movable structures that can be described by the same parametric system, measured in an identical set of criteria which perform analog physiological, biochemical, cognitive and conative mechanisms. Thus defined, motor abilities differ from motor habits and motor skills. That motor abilities are the result of complex abilities which enable man to manifest motor structures in certain activities that combine physical characteristics, biochemical processes and functional changes, was outlined by Kukolj (2006).

Zatsiorsky (1975) proposes a theoretical model of motor abilities in which he singled out the seven essential physical properties of man: strength, speed, endurance, coordination, balance, precision and mobility.

The ability of balance implies maintaining an equilibrium position in a state of relative rest static balance and in movement - dynamic balance. This ability is not understood as the ability to maintain position, but as the ability to quickly restore the equilibrium position, following its distortions in terms of mode, or in terms of movement (Kukolj, 2006). Balance is the ability to preserve a stable body position in a variety of movements (Višnjić, Jovanović, \& Miletić, 2004). Balance can be defined as basic motor ability of establishing and maintaining a stance of equilibrium or position in place and during movement. Although the physics and biomechanics distinguish stable, unstable and indifferent balance, in the latent space of human motor skills are defined: static, dynamic and equilibrium in balancing with an object. In addition to the above mentioned, factors of balance with open and closed eyes have been defined. The ability to balance is observed on the basis of changing the position of the body segments to maintain a certain position, the degree of stability of the body after the disruption of the balance position and stability in the course of further movement of the hands, head, etc. (Forti-Bellani \& Castilho-Weinert, 2011). Balance depends on the surface of the support. Increased difficulty is achieved with decreasing surface support by raising support, reducing and raising the surface of the palm, tilting the surface of the support, work on different types of surfaces. Balance is essential for maintaining each posture or position. As a motor ability, balance participates in all human movements. The proper functioning of balance allows people to see clearly as they move, orient themselves in space in accordance with gravity, determine the direction and speed of movement, and to automatically perform position correction and maintain the stability of the body in a variety of conditions and activities (Brauer, Woollacott, \& Shumway-Cook, 2001). Postural or balance control is an essential prerequisite for most daily life activities in children. It is the complex ability to maintain, achieve, or restore a state of balance while a person is stationary, preparing to move, in motion, or preparing to stop moving (Said, 2013: 190). Afferent input from the visual, vestibular, and proprioceptive systems are integrated and evaluated by central processing systems to generate motor responses that keep the body in balance (Buchman, Joy, Telischi, \& Balkany, 2004, according to Said, 2013). Balance dysfunctions may result in a very higher risk of injuries, especially in some situations that demand high - level balance ability, such as sports, recreational or other activities (Mao, Kuo, Yang, \& Su, 2014).

In relevant scientific and professional literature, there are studies that suggest that in children with intellectual disabilities the ability to maintain balance is reduced (Dellavia, Pallavera, Orlando \& Sforza, 2009; Hale, Miller, Barach, Skinner, \& Gray, 2009). According 
to the definition of the World Health Organization (WHO), intellectual disability is a state of impaired or incomplete psychological development, which is particularly characterized by a disorder of those abilities that emerge during the developmental period, which contribute to the general level of intelligence, such as cognitive, motor, speech and social abilities (WHO, 2011). Nedović \& Rapaić (2012) consider that motor and cognitive abilities are mutually related, and their interaction can be described in the case of dominant dysfunction in one area. The negative impact of intellectual disability, which is recognizable by deficits in the field of cognitive functioning, is reflected in the inability of children with intellectual disabilities to devise the goal, cognitively support planning, control and performance of motor activities.

Assessing balance as it pertains to motor ability is very present in scientific research. In children, balance develops in everyday activities through play and exercise. This information tells us about its importance which it has in everyday activities (Rajendran, Roy, \& Jeevanantham, 2012), in educational work or in school, at home, and in the community or in social life (Dolva, Coster, \& Lilja, 2004). According to the literature, a balance is necessary to maintain each posture or position. In that regard, for adequate implementation of educational work in school, it is necessary for students to have a good balance so that they can follow lessons in all subjects and to actively participate in physical activities, specifically in physical education classes (Bouffard, Watkinson, Thompson, Dunn, \& Romanow, 1996; Wall \& Kentala, 2010; Wilson, 2005). The period of early school age is an extremely sensitive phase for training movement, and training the majority of motor abilities. At this time, if we want to achieve developmental effects in this area, we must reach their incentives for adequate exercises. Positive stimuli corresponding to intensity in this period can cause increased adaptive reactions of the body, and under the influence of these stimulants may improve the development of motor abilities that give good results because of this action. Assessment of balance, as a motor ability, is a part of many scientific disciplines. However, in special education and rehabilitation there is little such research. Considering that, there is a reasonable need for this, especially if we know that today all children with developmental disorders or disabilities are obliged to attend school.

The aim of this pilot study was to evaluate the balance ability of younger school children with moderate intellectual disability and children with typical development.

\section{METHODS}

\section{Sample description}

The research sample was formed by 38 male students. The participants were divided into two groups. The first group (G1) consisted of 23 students with typical development, with an average age of 7.6 years. In the second group (G2) there were 15 students with moderate intellectual disability, with an average age of 7.8 years. All students attended first grade and had right-hand dominance extremities. Also, all the students were involved, only, in mandatory classes of physical education. The survey was conducted in Belgrade, in the three primary schools "Braća Baruh", "Novi Beograd" and "Sveti Sava". 


\section{The survey instrument}

Bruininks-Oseretsky Test of Motor Proficiency, 2nd edition-BOT 2 (Bruininks \& Bruininks, 2005), subtest 5 was used for the assessment the balance. This subtest assesses the skill of motor control, which is responsible for maintaining the posture of the body when the participant stands, walks or performs long activities such as reaching for a cup, which is located on a shelf. Tasks in this subtest measures three areas covered by balance: the stability of the walk, move and stop, and the use of visual cues. There are nine items (tasks) that are used to evaluate the stability of the fuselage with the possibility of standing on both legs, one leg, standing on the floor and on the beam. The movement and stop are measured by the seven items that include stationary balance, and two items that examine the possibility of walking on a line. Of all the tasks, three are running with eyes closed, to assess the extent to which visual stimuli are necessary to maintain balance. The participants has the right to two attempts, and as a result takes the one that is better. The tasks within subtest 5 are shown in Table 1.

Table 1 Balance subtest scores of the Bruininks-Oseretsky Test of Motor Proficiency

\begin{tabular}{lrc}
\hline Balance subtest tasks & Raw score maximum & Point score \\
\hline Standing with feet apart on a line - Eyes open (s) & 10 & $0-4$ \\
Walking forward on a line (steps) & 6 & $0-4$ \\
Standing on one leg on a line - Eyes open (s) & 10 & $0-4$ \\
Standing with feet apart on a line - Eyes closed (s) & 10 & $0-4$ \\
Walking forward heel to toe on a line (steps) & 6 & $0-4$ \\
Standing on one leg on a line - Eyes closed (s) & 10 & $0-4$ \\
Standing on one leg on a balance beam - Eyes open (s) & 10 & $0-4$ \\
Standing heel-to-toe on a balance beam (s) & 10 & $0-4$ \\
Standing on one leg on a balance beam - Eyes closed (s) & 10 & $0-5$ \\
\hline Total score (1-9) & & $0-37$ \\
\hline
\end{tabular}

\section{Statistical analysis}

Statistical analyses were performed using the SPSS version 21.0 software (SPSS Inc., Chicago, IL, USA). The Shapiro-Wilks test was used to test the normal distribution of all parameters, independent samples t-test was used to test differences in continuous variables between groups. Statistical significance was calculated at the $\mathrm{p}<0.05$ level. Also, measures of descriptive statistics (mean and standard deviation) were used for the analysis of the results. The raw results (row score) were converted into points which were compared with the norms of the scale scores and norms for age, according to the instructions for use of the test.

\section{RESULTS}

Table 2 shows the normality of the distribution of the tested parameters. The test values were higher than $p>0.05$. So, it was acceptable to assume that the distribution of data for both groups was normally distributed. 
Table 2 Normality of the distribution of the tested parameters

\begin{tabular}{ccccccc}
\hline Task & \multicolumn{5}{c}{ Shapiro - Wilks Test } \\
\cline { 2 - 7 } & \multicolumn{4}{c}{ Group 1 } & \multicolumn{3}{c}{ Group 2 } \\
\cline { 2 - 7 } & Statistics & df & Sig. & Statistics & df & Sig \\
\hline Task 1 & .943 & 23 & .106 & .918 & 15 & .179 \\
Task 2 & .894 & 23 & .076 & .900 & 15 & .094 \\
Task 3 & .899 & 23 & .114 & .892 & 15 & .071 \\
Task 4 & .902 & 23 & .144 & .903 & 15 & .107 \\
Task 5 & .876 & 23 & .091 & .902 & 15 & .101 \\
Task 6 & .799 & 23 & .081 & .893 & 15 & .073 \\
Task 7 & .906 & 23 & .119 & .937 & 15 & .078 \\
Task 8 & .889 & 23 & .064 & .916 & 15 & .167 \\
Task 9 & .983 & 23 & .187 & .718 & 15 & .054 \\
\hline
\end{tabular}

The average achievements of the participants on tasks within subtest 5 are displayed in Table 3 .

It can be said that the mean value in tasks, for group 1, ranges from 2.78 to 4.00 (SD = $1.278-.000)$. The worst achievement the participants made was in task No. $9(\mathrm{M}=2.78, \mathrm{SD}$ $=1.278)$, while the best average achievement was recorded in the first task $(\mathrm{M}=4.00, \mathrm{SD}=$ .000). Total average achievement of the students in Group 1 for all the tasks was 31.07. At the same time, the participants from Group 2 had average achievement in all tasks ranging from .67 to $2.60(\mathrm{SD}=.488-.507)$. Top achievements were realized in the first task $(\mathrm{M}=2.60$, $\mathrm{SD}=.507)$, and the worst for task No. $4(\mathrm{M}=.67, \mathrm{SD}=.488)$. Total average achievement for group 2 was 11.34 .

Table 3 Average achievement of the participants on tasks within subtest 5

\begin{tabular}{lcccccc}
\hline Task & Group & $\mathrm{N}$ & Min & Max & Mean & Std. Deviation \\
\hline Task 1 & G1 & 23 & 4 & 4 & 4.00 & .000 \\
& G2 & 15 & 2 & 3 & 2.60 & .507 \\
\hline Task 2 & G1 & 23 & 2 & 4 & 3.91 & .417 \\
& G2 & 15 & 1 & 2 & 1.40 & .507 \\
\hline Task 3 & G1 & 23 & 3 & 4 & 3.78 & .422 \\
& G2 & 15 & 1 & 2 & 1.27 & .458 \\
\hline Task 4 & G1 & 23 & 1 & 4 & 3.61 & .839 \\
& G2 & 15 & 0 & 1 & .67 & .488 \\
\hline Task 5 & G1 & 23 & 1 & 4 & 3.78 & .736 \\
& G2 & 15 & 1 & 2 & 1.27 & .458 \\
\hline Task 6 & G1 & 23 & 1 & 4 & 2.65 & 1.152 \\
& G2 & 15 & 0 & 2 & 1.07 & .594 \\
\hline Task 7 & G1 & 23 & 2 & 4 & 3.43 & .896 \\
& G2 & 15 & 1 & 1 & 1.00 & .000 \\
\hline Task 8 & G1 & 23 & 1 & 4 & 3.13 & 1.058 \\
& G2 & 15 & 1 & 2 & 1.33 & .488 \\
\hline Task 9 & G1 & 23 & 1 & 5 & 2.78 & 1.278 \\
& G2 & 15 & 0 & 2 & .73 & .594 \\
\hline
\end{tabular}


Table 4 Statistical analysis for the examined tasks

\begin{tabular}{lrlrl}
\hline Task & \multicolumn{1}{c}{$\mathrm{F}$} & Sig & $\mathrm{t}$ & $\mathrm{df}$ \\
\hline Task 1 & 522.947 & $\mathbf{. 0 0 0}^{*}$ & 13.340 & 36 \\
Task 2 & 9.645 & $\mathbf{. 0 0 4}^{*}$ & 16.672 & 36 \\
Task 3 & .447 & .508 & 17.384 & 36 \\
Task 4 & 1.278 & .266 & 12.263 & 36 \\
Task 5 & .001 & .972 & 11.805 & 36 \\
Task 6 & 14.391 & $\mathbf{. 0 0 1}^{*}$ & 4.905 & 36 \\
Task 7 & 58.949 & $\mathbf{. 0 0 0}^{*}$ & 10.477 & 36 \\
Task 8 & 11.592 & $\mathbf{. 0 0 2}^{*}$ & 6.146 & 36 \\
Task 9 & 7.352 & $\mathbf{. 0 1 0}^{*}$ & 5.797 & 36 \\
\hline
\end{tabular}

Note: the level of significance is $\mathrm{p}<0.05$

Table 4 shows the results obtained by the statistical analysis of the t-test. As we can see from the results shown in Table 4, a highly statistically significant difference in the t-test was obtained for six of the nine tested tasks $(\mathrm{p}<0.05)$ : Standing with feet apart on a line - Eyes open $(\mathrm{F}=522,947, \mathrm{p}=.000, \mathrm{t}=13.340, \mathrm{df}=36)$; Walking forward on a line $(\mathrm{F}=9.645$, $\mathrm{p}=.004, \mathrm{t}=16.672$, df $=36)$; Standing on one leg on a line - Eyes closed $(\mathrm{F}=14.391$, $\mathrm{p}=.001, \mathrm{t}=4.905, \mathrm{df}=36$ ); Standing on one leg on a balance beam - Eyes open $(\mathrm{F}=58,949, \mathrm{p}=.000, \mathrm{t}=10.477, \mathrm{df}=36)$; Standing heel-to-toe on a balance beam $(\mathrm{F}=11.592, \mathrm{p}=.002, \mathrm{t}=6.146, \mathrm{df}=36)$; Standing on one leg on a balance beam - Eyes closed $(\mathrm{F}=7.352, \mathrm{p}=.010, \mathrm{t}=5.797, \mathrm{df}=36)$.

\section{DISCUSSION}

Balance is essential for learning, and participation in educational work, in school and physical activities. The results of our study are consistent, to a certain extent, with the results obtained by other authors. Mombarg, Jelsma, \& Hartman (2013) conducted a research on 29 children with poor motor performance, and concluded that the total score on subtest 5 (BOT2) in the experimental group was 24.3 and 29.7 in the control group. In our research, children with typical development had a total score 31.07 , while children with intellectual disabilities had 11.34. Franjoine, Darr, Held, Kott, \& Young (2010) obtained information that $69.1 \%$ of the participants won the maximum score on the balance test, while our results show that only $5.26 \%$ of the students won the maximum score on subtest 5 . The results obtained in similar studies, which we can find in the available literature, indicate that the balance disorder is present in $28.7 \%$ of the students of the typical population (Nikolić \& IlićStošović, 2009). In our research $86.8 \%$ of the total sample has a balance disorder, while this disorder was recorded in $47.37 \%$ of the students with typical development. In other research, we can find that children with Attention Deficit Hyperactivity Disorder (ADHD) have impaired dynamic balance. Respectively, they had less consistent patterns of movement and a more extended arc for trial and error in their attempt to maintain dynamic balance (Mao et al, 2014). Some earlier studies (Henderson et al, 1981; Nakamura, 1965; all according to Connolly \& Michael, 1986) indicated that children with Down syndrome have more difficulty with balance than children with intellectual disabilities but without Down syndrome. 
Confirmation of the fact that children with intellectual disability with delays in psychomotor development compared to their peers of typical development, can be found in the work of Vuijk, Hartman, Scherder, \& Visscher (2010). These authors used the Movement Assessment Battery for Children (MABC test) to evaluate the motor performance of children (7-12 years) with mild intellectual disability and boundary levels of intellectual functioning, in four areas: manual skills, skills with a ball, as well as static and dynamic balance. Data collected during the survey point to the conclusion that children with intellectual disability had significantly more motor problems in performing the given actions in relation on the normative sample. Among other things, there was a connection between the level of intellectual disabilities and the achievement of postural balance tasks. The negative correlation between the quality of balance and the level of intellectual disability was found in the research of Green et al. (2009). Intellectual skills have proven to be an important factor. Children whose Intelligence Quotation (IQ) was less than 70 achieved lesser success in assessing balance than children with higher intellectual abilities (IQ $\geq 70)$.

Although it is well known that poor balance is most evident among individuals with intellectual disabilities, our study shows that children with typical development have poor balance, also. Today, these results could be the consequence of a modern lifestyle, which is primarily sedentary. In other words, these results can point out the possible poor participation of students with intellectual disability in physical activities, which is unambiguous if we know that motor problems in students with intellectual disability are registered as commonplace, because intellectual disability is a factor that affects cognitive and motor functions (Cleaver, Hunter, \& Ouellette-Kuntz, 2009; Hartman, Houwen, Scherder, \& Visscher, 2010; Vuijk et al., 2010).

In further analysis, our results were compared with the norms given by the authors of the test Bruininks \& Bruininks (2005) and it was found that the students with typical development are within average, while the participants with moderate intellectual disabilities are below average. When we compared the results with age norms, which were given by these authors, the obtained data is that participants with typical development corresponded to the ages from 7 to 7.2 , and participants with moderate intellectual disabilities under the age of 4. Many authors agree that the average results of children with intellectual disabilities on the tests for the assessment of balance are lagging behind the average results of children from the population of normal intellectual abilities of the same chronological age (Graham, \& Ried, 2000; Pitetti, Millar, \& Fernhall, 2001; Lotan, Isakov, Kessel, \& Merrick, 2004; Kosma, Acock, Rintala, \& Wood, 2004; Pappa, Evaggelinou, Varda, Giagazoglou, \& Goudesidou, 2004; Carmeli, Bar-Yossef, Ariav, Levy, \& Liebermann, 2008; Frey \& Chow, 2006, all according to Protić-Gava \& Uskoković, 2016). Wickstrom (1983) concluded that the delay in the development of balance in children with intellectual disabilities was two to four years in comparison to the children of normal intellectual abilities of the same chronological age.

If the children recorded poor balance, there is a possibility that other motor abilities were underdeveloped or compromised by other factors, which limits the person's autonomy in everyday activities, and their participation in school. This claim can be corroborated by the results of a study conducted by The Serbian Institute of Sport and Sports Medicine (Gajević, 2009). The results show that the secular trend in the development of motor abilities of students is going in a negative direction, i.e. that a reduction of the motor abilities occurs at the elementary school level. In this case, the obtained results are not unexpected. Numerous studies show that this trend is present in other countries in the world (Telama et al., 2002; 
Corder, van Sluijs, Ekelund, Jones, \& Griffin, 2010; Runhaar et al., 2010; Dumith, Gigante, Domingues, \& Kohl, 2011; Badrić, Sporiš, Trklja, \& Petrović, 2012, all according to Milojević, Marković, Gadžić, \& Stanković, 2014).

Giagazoglou et al. (2013) note that the program of exercise on the trampoline, in which students can be involved, proved to be an effective intervention measure to improve balance, and it can be recommended as a model in programs of physical activity. Also, it is considered that motor abilities of children with intellectual disabilities represent an area which can be most influenced in their educational process and can prepare them better for their personal, working and defensive integration into social life, in order to make their socialization, and even self-actualization as effective as possible. Because of this, in the area of motor abilities, significant discriminators can be observed in relation to the population of children with normal intellectual abilities (Fejgin, Talmor, \& Erlich, 2005).

\section{CONCLUSION}

The data obtained in our study showed that students with typical development have balance developed on an average level, while among students with intellectual disability balance it is developed below average. In other words, balance is affected in children with intellectual disability compared to their age-matched peers in the general population. This problem starts at a young age, and remains present during the entire lifespan of persons with intellectual disabilities.

This study has several limitations: a relatively small sample, the participants were exclusively male, only balance was assessed of the motor abilities, certain anthropometric characteristics were not taken into account, and the like. We believe that the next survey should include a significantly larger number of participants of different sexes and ages, with different physical characteristics and capabilities, as well as certain cognitive, sensory and motor disorders. Also, it would be important to compare the achievements in motor abilities and the success of students in school. This comparison will give us insight into just how important of a factor motor abilities are for teaching various subjects. The obtained results of this study can be used as a basis for further research in the field of (special) education and rehabilitation. They can be used to create programs of preventive and corrective work in order to support and assist students in school activities, also.

\section{REFERENCES}

Bouffard, M., Watkinson, E.J., Thompson, L.P., Dunn, J.L.C., \& Romanow, S.K.E. (1996). A test of the activity deficit hypothesis with children with movement difficulties. Adapted Physical Activity Quarterly, 13(1), 61-73.

Brauer, S.G., Woollacott, M., \& Shumway-Cook, A. (2001). The interacting effects of cognitive demand and recovery of postural stability in balance-impaired elderly persons. The Journals of Gerontology Series A: Biological Sciences and Medical Sciences, 56(8), M489-M496.

Bruininks, R., \& Bruininks, B. (2005). Bruininks-Oseretsky Test of Motor Proficiency, second edition (BOT2). Minneapolis, MN: Pearson Assessment

Cleaver, S., Hunter, D., \& Ouellette-Kuntz, H. (2009). Physical mobility limitations in adults with intellectual disabilities: A systematic review. Journal of Intellectual Disability Research, 53, 93-105.

Connolly, B.H. \& Michael, B.T. (1986). Performance of retarded children, with and without Down syndrome, on the Bruininks Oseretsky Test of Motor Proficiency. Physical Therapy, 66, 344-348. 
Dellavia, C., Pallavera, A., Orlando, F., Sforza, C. (2009). Postural stability of athletes in Special Olympics. Perceptual and Motor Skills, 108(2), 608-622.

Dolva, A.S., Coster, W., \& Lilja, M. (2004). Functional performance in children with Down syndrome. American Journal of Occupational Therapy, 58, 612-629.

Franjoine, M.R., Darr, N., Held, S.L., Kott, K., \& Young, B.L. (2010). The performance of children developing typically on the pediatric balance scale. Pediatric Physical Therapy, 22 (4), 350-359.

Fejgin, N., Talmor, R., Erlich, I. (2005). Inclusion and burnout in physical education. European Physical Education Review, 11(1), 29 -50.

Forti-Bellani, C.D., \& Castilho-Weinert, L.V. (2011). Desenvolvimento motor tipico, desenvolvimento motor atipico e correlações na paralisia cerebral (Typical motor development, atypical motor development and correlations in cerebral palsy). In L.V. Castilho-Weiner \& C.D. Forty-Bellini (Eds.), Fisioterapia em Neuropediatria, (pp. 1 - 22), Curitiba: Omnipax. In Portugais

Gajević, A. (2009). Fizička razvijenost i fizičke sposobnosti dece osnovnoškolskog uzrasta (Physical development and physical abilities of children in elementary school). Belgrade: The Serbian Institute of Sport and Sports Medicine. In Serbian

Giagazoglou, P., Kokaridas, D., Sidiropoulou, M., Patsiaouras, A., Karra, C., \& Neofotistou, K. (2013). Effects of a trampoline exercise intervention on motorperformance and balance ability of children with intellectual disabilities. Research in Developmental Disabilities, 34, 2701-2707.

Green, D., Charman, T., Pickles, A., Chandler, S., Loucas, T., Simonoff, E., \& Baird, G. (2009). Impairment in movement skills of children with autistic spectrum disorders. Developmental Medicine \& Child Neurology, 51(4), 311-316.

Hale, L., Miller, R., Barach, A., Skinner, M., Gray, A. (2009). Motor Control Test responses to balance perturbations in adults with an intellectual disability. Journal of Intellectual and Developmental Disability, 34(1), 81-86.

Hartman, E., Houwen, S., Scherder, E., \& Visscher, C. (2010). On the relationship between motor performance and executive functioning in children with intellectual disabilities. Journal of Intellectual Disability Research, 54(5), 468-477.

Kukolj, M. (2006). Antropomotorika (Anthropomotorics). Belgrade: Faculty of Sport and Physical Education. In Serbian

Mao, H.Y., Kuo, L.C., Yang, A.L., \& Su, C.T. (2014). Balance in children with attention deficit hyperactivity disorder-combined type. Research in Developmental Disabilities, 35 (6), 1252-1258.

Milojević, A., Marković, E., Gadžić, A., \& Stanković, V. (2014). Developmental characteristics of motor abilities of high school girls. Facta universitatis Series Physical Education and Sport, 12 (3), 261-273.

Mombarg, R., Jelsma, D., \& Hartman, E. (2013). Effect of Wii-intervention on balance of children with poor motor performance. Research in Developmental Disabilities, 34, 2996-3003.

Nedović, G., \& Rapaić, D. (2012). Praktikum preventivno-korektivnog rada u osnovnoj školi. (Practicum of preventive and corrective work in elementary school). Belgrade: BIG print. In Serbian

Nikolić, S., \& Ilić-Stošović, D. (2009). Detection and prevalence of motor skill disorders. Research in Developmental Disabilities, 30, 1281-1287.

Protić-Gava, B.V., \& Uskoković, F.R. (2016). Differences between the motor abilities of students attending a regular secondary school and those attending a secondary school for the education of children with disabilities. Facta Universitatis, Series Physical Education and Sport, 14 (1), 43-50.

Rajendran, V., Roy, F.G., \& Jeevanantham, D. (2012). Postural control, motor skills, and health-related quality of life in children with hearing impairment: a systematic review. European Archives of Oto - Rhino Laryngology, 269 (4), 1063-1071.

Said, E. (2013). Clinical balance tests for evaluation of balance dysfunction in children with sensorineural hearing loss. The Egyptian Journal of Otolaryngology, 29, 189-201.

Višnjić, D., Jovanović, A., \& Miletić, K. (2004). Teorija i metodika fizičkog vaspitanja (Theory and methodics of physical education). Belgrade: Faculty of Sport and Physical Education. In Serbian

Vuijk, P.J., Hartman, E., Scherder, E., \& Visscher, C. (2010). Motor performance of children with mild intellectual disability and borderline intellectual functioning. Journal of Intellectual Disability Research, 54 (11), 955-965.

Wall, C., \& Kentala, E. (2010). Effect of displacement, velocity, and combined vibrotactile tilt feedback on postural control of vestibulopathic subjects. Journal of Vestibular Research: Equilibrium and Orientation, 20(1), 61-69.

Wickstrom, R.L. (1983). Fundamental movement patterns. Philadelphia: Lea \& Febiger

Wilson, P.H. (2005). Practitioner review: Approaches to assessment and treatment of children with DCD: An evaluative review. Journal of Child Psychology and Psychiatry, 8, 806-823. 
World Health Organization (2011). International statistical classification of diseases and related health problems - 10th revision, Edition 2010, Volume 2.

Zatsiorsky, V. (1975). Fizička svojstva sportista (Physical properties of athletes). Belgrade: NIP Partizan. In Serbian

\section{PROCENA RAVNOTEŽE KOD DECE SA INTELEKTUALNOM OMETENOŠĆU MLAĐEG ŠKOLSKOG UZRASTA}

Kod dece, balans se razvija u svakodnevnim aktivnostima kroz igru i vežbanje. Od suštinskog je značaja za učenje, i učešće u obrazovnom radu i fizičkim aktivnostima. Cilj ovog istraživanja je bio da se proceni balans kod dece mlađeg uzrasta tipičnog razvoja $i$ kod dece sa umerenom intelektualnom ometenošću. Istraživanje je sprovedeno u novembru 2014. godine, na uzorku od 38 dečaka (23 tipičnog razvoja i 15 sa umerenom intelektualnom ometenošću). Za procenu balansa korišćen je Bruininks - Oseretski Test motoričkih sposobnosti, drugo izdanje - BOT 2 (Bruininks \& Bruininks, 2005), $i$ to subtest 5. Rezultati istraživanja su pokazali da je ukupno prosečno postignuće dece tipičnog razvoja na svim zadacima 31.07 poena, dok kod dece sa intelektualnom ometenošću iznosi 11.34. Statistički značajna razlika ostvarena je na 6 od 9 zadataka $(p<0.05)$. $U$ poređenju sa normama, deca tipičnog razvoja se nalaze bliže proseku, dok su ispitanici sa umerenom intelektualnom ometenošću ispod proseka na balans testu. Dobijeni rezultati ove studije, mogu se koristiti kao osnova za dalja istraživanja u oblasti (specijalne) edukacije $i$ rehabilitacije. Takođe, mogu se koristiti za kreiranje programa preventivnog $i$ korektivnog rada $u$ cilju podrške i pomoći učenicima u školskim aktivnostima.

Ključne reči: BOT -2, deca sa intelektualnom ometenošću, deca tipičnog razvoja, motoričke sposobnosti 